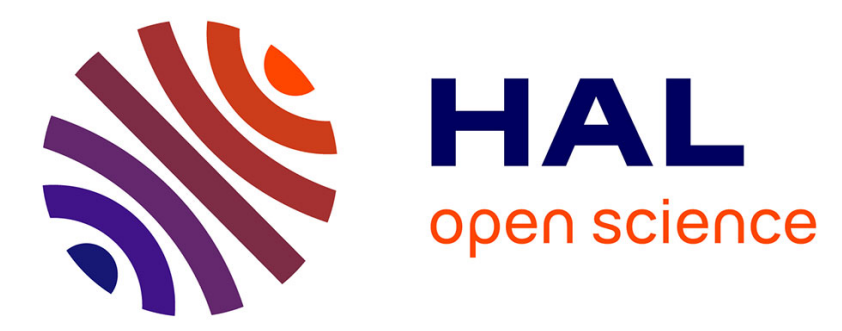

\title{
Recent trends in steel making and their implications on mechanical properties
}

\author{
F. Mudry
}

\section{To cite this version:}

F. Mudry. Recent trends in steel making and their implications on mechanical properties. Journal de Physique IV Proceedings, 1993, 03 (C7), pp.C7-51-C7-59. 10.1051/jp4:1993705 • jpa-00251711

\section{HAL Id: jpa-00251711 \\ https://hal.science/jpa-00251711}

Submitted on 1 Jan 1993

HAL is a multi-disciplinary open access archive for the deposit and dissemination of scientific research documents, whether they are published or not. The documents may come from teaching and research institutions in France or abroad, or from public or private research centers.
L'archive ouverte pluridisciplinaire HAL, est destinée au dépôt et à la diffusion de documents scientifiques de niveau recherche, publiés ou non, émanant des établissements d'enseignement et de recherche français ou étrangers, des laboratoires publics ou privés. 


\title{
Recent trends in steel making and their implications on mechanical properties
}

\author{
F. MUDRY
}

USINOR SACILOR, 4 place de la Pyramide, 92070 Paris la Defense cedex 33, France

\begin{abstract}
A very general overview of the technical trends in the steelmaking industry is given. Based on a very crude classification of the products, the advantages and disadvantages of the different production routes are discussed. This includes the liquid steel production either from scrap or from iron ore. Then the production routes using the new developments on thin slab or strip casting are compared to these using the more conventional continuous casting. Finally, the development of the on line continuous heat treatments and of the coating processes is briefly discussed. Based on these considerations, a description of the different kinds of steelmaking plants that we may have in the future, is attempted.
\end{abstract}

Introduction : The steel industry has been drastically changing in the previous years, and these changes are continuing nowadays. The purpose of this short review is a description of the different technological changes which may take place in the future and their relations to the properties of the steels which will be produced following these new routes.

This survey will be divided into 4 parts. The first part, wich will be more developed will deal with the different routes of crude liquid steel production in relationship to the level of chemical impurities required by each type of product

The second part will concentrate on the new techniques of direct casting of slabs, strips or wires.

The third one, on the developpment of thermo mechanical controlled processes on and off line.

Finally, a fourth part will give a brief insight into the different coating techniques used in the steel industry.

\section{1 - LIQUID STEEL PRODUCTION}

Roughly, two different routes are used for steel making in western countries. The first one, starts from iron ore which is reduced in the blast furnace in the presence of coke. The pig iron is then oxydized to remove carbon in the blast oxygene furnace (BOF). The second route makes use of the electric arc furnace (EAF) to melt scrap and produces directly liquid steel. A major trend of these last years is a constant increase of the proportion of steels made from scrap through the EAF, figure 1 (1).

This trend will continue for some time for several reasons :

1 - the cost efficiency of the second route, is usually better

2 - the price of scrap may be variable on the short term but, on the long term, the availability of scrap is sufficient in the developed countries to allow a major proportion (up to $60 \%$ ) of the crude steel production to be made from scrap (2)

3 - probably more important, the capital expenditure is a lot lower 


\section{FIGURE 1 : EAF CRUDE STEEL PRODUCTION PROPORTION}

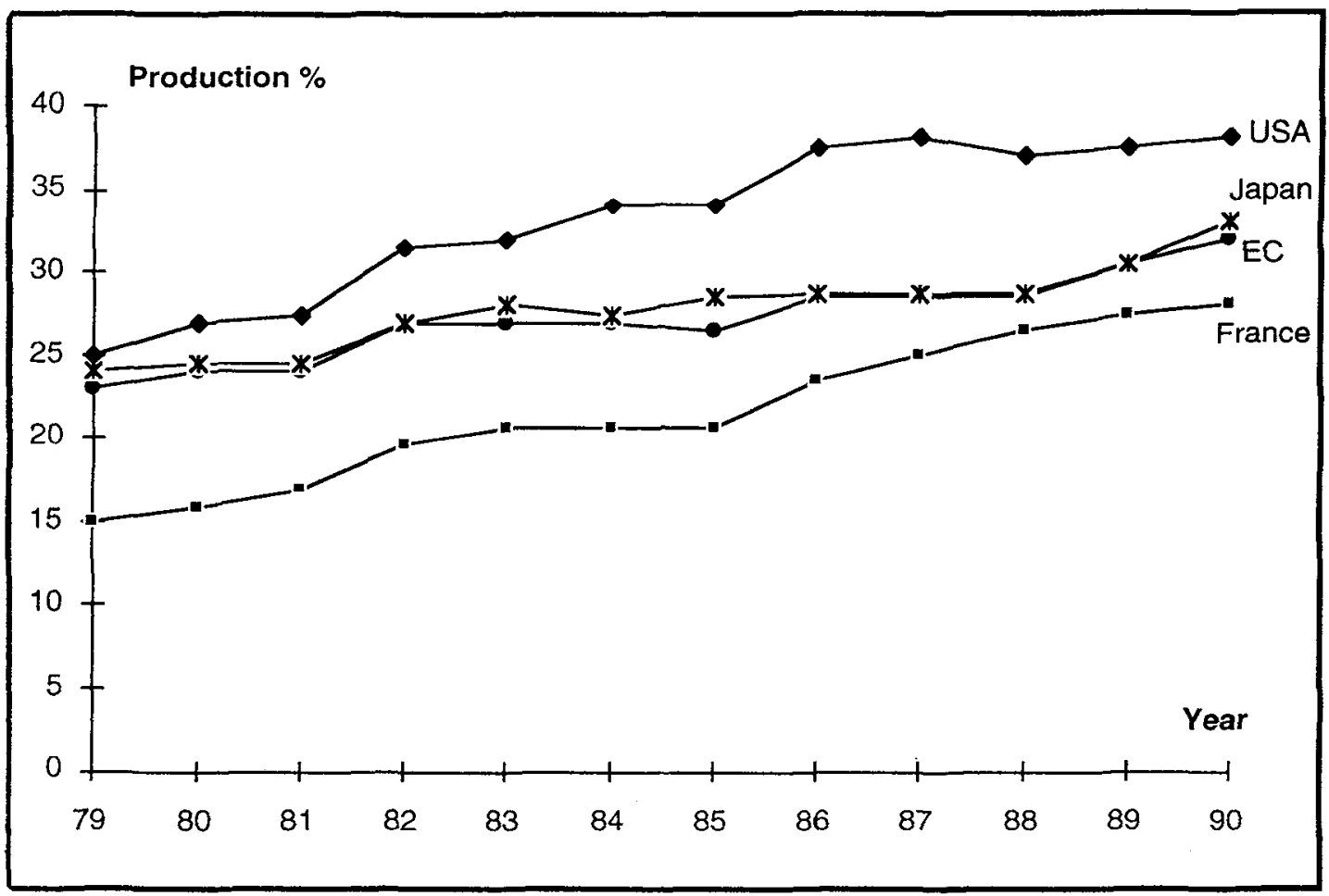

4 - the environmental regulations will tend to close down the obsolete coke units and to enhance the proportion of scrap effectively recycled

Therefore, the question is not: "will the proportion continue to grow in the future ?" but "to what proportion will it continue to grow ?"

For this second question, the limit, as explained in reference $(2,3,4)$ will not be the availability of scrap at competitive prices but the proportion of metallurgical products which may be processed through this route with the quality level compatible with the metallurgical characteristics.

To go further into this, we will divide roughly the different products into three categories depending on their required level of impurity in non metallic and metallic elements (4). Stainless Steel is excluded of this survey.

\section{2 - THREE CATEgORIES OF PRODUCTS}

\section{1 - High formabiliy fine steels}

The word "fine steel" is taken from the japanese litterature on the subject as an equivalent to "quality steels".

The first category will include steels with a very high cold formability e.g.. deep drawing sheets, tinplates, high drawability wires, etc.... The required tensile strength of these steels in not very high but their ductility and strain hardening properties must be very high. Furthermore, lower and lower thicknesses will be required. That is why the content of non metallic precipitates such as carbides, nitride sulphides etc... must be minimized. Futhermore, this will improve the coating process as well as the recristallization characteristics (5). The only drawback could be grain growth during welding. 
Besides a minimized inclusions content, the level of interstitials which are free in the matrix, specially C and $\mathrm{N}$ must be zero to avoid the formation of Lüders Bands which lead to poor aspects of the products after deformation, and to obtain the highest drawability

Furthermore, the content of metallic elements such as $\mathrm{Cu}, \mathrm{Ni}$, Mo, must be minimized to avoid defects during the processing of the hot solid metal. The process of hot cracking is usually connected with the content of such metallic impurities notably copper. This leads to defects which may be catastrophic during cold forming. For example, a susceptibility index for high temperature cracking is three time larger when the Copper content is increased from $0,2 \%$ to $0,3 \%$

The description is somewhat simplified and some products may fall in this category though their strength is higher. In this case some hardening must be attained by additions of phosphorous, silicium, manganese, etc...

Other reasons than the high temperature deformability may be invoked for the low level of metallic elements required (e.g. weldability for welding electrodes, etc...) However, the majority of the steels falling into this category are correctly described by the previous considerations

Table 1 taken from reference (6) gives some figures for some products of this category in present day production. Futhermore, new products require very low contents of metallö̈ds, especially $\mathrm{N}$ and $\mathrm{C}$

TABLE 1 : APPROXIMATE REQUIRED CONTENTS OF METALLIC RESIDUALS IN CATEGORY 1 PRODUCTS, FROM REFERENCE (5)

\begin{tabular}{|c|c|c|c|c|c|c|}
\hline $\begin{array}{l}\left.\text { Element content (in } 10^{-3} \%\right) \\
\text { Product / Application } \\
\end{array}$ & $\mathbf{N i}$ & $\mathrm{Cr}$ & $\mathrm{Cu}$ & Sn & Mo & Other \\
\hline Hot-rolled sprip "increased purity" & & & 100 & & & $\Sigma$ metallics $<150$ \\
\hline $\begin{array}{c}\text { Cold rolled sheets } \\
\text { CQ } \\
\text { DQ } \\
\text { DDQ \& estra DDQ } \\
\end{array}$ & 80 & & $\begin{array}{c}100 \\
80\end{array}$ & & & $\begin{array}{l}\Sigma \text { metallics }<200 \\
\Sigma \text { metallics }<150 \\
\Sigma \text { metallics }<100\end{array}$ \\
\hline Quality electrodes for welding & 100 & 100 & 100 & 20 & & $\mathrm{Ni}+\mathrm{Cr}+\mathrm{Cu}<300$ \\
\hline Saw electrodes & 150 & 150 & 120 & & & \\
\hline High cold formability wires & 200 & 100 & 150 & & & $\mathrm{Ni}+\mathrm{Cr}+\mathrm{Cu}<350$ \\
\hline High drawability, high Cobars wires & 200 & 150 & 120 & & 80 & $\mathrm{Ni}+\mathrm{Cr}+\mathrm{Cu}<340$ \\
\hline
\end{tabular}

A rough estimate of the percentage of steels produced in this first category will be between 30 and $35 \%$ of the total production. This proportion is only an approximation since no clear cut limit may be drawn between each category of products.

For this category, the goal is, therefore, almost pure iron. The very high level of purity required may only be reached through the iron ore route and a sophisticated preparation of the liquid metal inculding pig iron desulphurization or dephosphoration and/or ladle metallurgy and in particular vacuum treatment.

\section{2 - Special fine steels}

This second category is much more heterogeneous. It includes products with larger sections like plates, beams or bars and with some property at a very high level of quality for example :

- resistance to $\mathrm{H}_{2} \mathrm{~S}$ embrittlement in pipelines

- resistance to wear in rails or bearing steels

- good quenchability in heat treated structural steels

- ultrahigh strength in high carbon wires

- etc... 
Some of these high strength steels must also exhibit a good cold formability. Moreover some of these products (plates, rails, ...) must be welded.

In these cases, the hardness will be gained using carbon, of course, but the weldability requires that the "carbon equivalent" be minimized (C.E. $=\mathrm{C}+\frac{\mathrm{Cu}}{3}+\frac{\mathrm{Mo}}{4}+\frac{\mathrm{Mn}}{6}+\frac{\mathrm{Ni}}{15}+\frac{\mathrm{Cn}}{15}$ ) to avoid cold cracking.

As well, a sufficiently low content of some metallic elements (notably $\mathrm{Cu}$ and $\mathrm{Ni}$ ) and of non metallic elements such as $\mathrm{S}$ and $\mathrm{P}$ is imposed to avoid hot cracking. For other applications (rails, bearing steels, engineering steels), the fatigue properties are the limiting factor. In this case, the content of inclusions such as sulphides, oxydes and nitrides has to be minimum. The most obvious way to reach this goal is to reduce the content of $\mathrm{S}, \mathrm{O}$ and $\mathrm{N}$ in the liquid metal.

Finally, some of these products may be very sensitive to the hydrogen "flaking" ; that is why very low hydrogen contents are required.

In such products, the chemical content of metalloïd elements must be carefully designed.but the requirements concerning the metallic elements are less stringent than for the first category of high formability fine steels.

Examples of such current requirements are given in table 2 (6)

TABLE 2 : APPROXIMATE REQUIRED CONTENTS OF METALLIC RESIDUALS IN CATEGORY 2 PRODUCTS, FROM REFERENCE (5)

\begin{tabular}{|c|c|c|c|c|c|c|}
\hline $\begin{array}{l}\left.\text { Element content (in } 10^{-3} \%\right) \\
\text { Product / Application }\end{array}$ & $\mathbf{N i}$ & $\mathrm{Cr}$ & $\mathbf{C u}$ & Sn & Mo & Other \\
\hline $\begin{array}{l}\text { Plate structural applications : } \\
\text { General } \\
\text { Increased purity } \\
\text { Pipelines }\end{array}$ & $\begin{array}{l}300 \\
200 \\
300\end{array}$ & $\begin{array}{l}250 \\
200 \\
200\end{array}$ & $\begin{array}{l}350 \\
300 \\
300\end{array}$ & & $\begin{array}{l}100 \\
100 \\
100\end{array}$ & $\begin{array}{l}\mathrm{Cu}+6 \mathrm{Sn} \leq 330 \\
\mathrm{C} \mathrm{eq}<410\end{array}$ \\
\hline $\begin{array}{l}\text { Hot rolled strip of everage quality } \\
\text { (low C-steel) }\end{array}$ & 250 & 250 & 300 & & 80 & \\
\hline Railway applications & 300 & 200 & 250 & & 100 & \\
\hline $\begin{array}{l}\text { Quality engineering steels bars } \\
\text { (general) }\end{array}$ & 250 & 200 & 300 & & 60 & \\
\hline $\begin{array}{l}\text { Quality engineering steels for heat } \\
\text { treatment }\end{array}$ & 400 & 400 & & 100 & & $\Sigma$ metallics $\leq 450$ \\
\hline
\end{tabular}

Once again, an exact proportion of products of this second category is difficult to assess but figures between 15 and $18 \%$ have been given.

\section{3 - Commodity steels}

This third category includes many steels for application in the building and construction industry. These may be flat or long products. Some examples are given in table 3 together with requirements on the metallic elements.

Since the chemical purity required for this kind of steel is less stringent, it may be easily processed from scrap through the EAF route. 
It is important to recognize that this third category may concern more than $50 \%$ of the total weight of the steels produced!

TABLE 3 : APPROXIMATE REQUIRED CONTENTS OF METALLIC RESIDUALS IN CATEGORY 3 STEELS, FROM REFERENCE (5)

\begin{tabular}{|l|c|c|c|c|c|l|}
\hline $\begin{array}{c}\text { Element content (in 10-3 \%) } \\
\text { Product / Application }\end{array}$ & Ni & Cr & Cu & S n & Mo & \multicolumn{1}{|c|}{ Other } \\
\hline Hot rolled strip of general quality & 250 & 250 & 350 & & 80 & \\
\hline Structural steel beams & 250 & 250 & 300 & & 80 & \\
\hline Concrete reinforcing steels & 400 & 500 & 700 & & 400 & $\mathrm{Cu}+6 \mathrm{Sn}<350$ \\
\hline Engineering steels for heat treatment & 400 & 300 & & 150 & & $\Sigma$ metallics $\leq 800$ \\
\hline Average hot forging steels & 400 & 250 & 300 & & 100 & $\Sigma$ metallics $\leq 800$ \\
\hline
\end{tabular}

\section{4 - Production route for each category:}

We will very briefly discuss the different technical limitations of the processing routes from the point of view of metal purity.

Table 4 gives typical figures of the content in metallic elements of molten scrap (1). A typical composition of pig iron is also given for comparison. The metallic elements are almost impossible to remove economically from the molten steel. Silicium is the only element which is present in a noticeable amount in pig iron. Therefore, a quick comparison with tables 1,2,3 shows that category 1 steel cannot be made from scraps and that category 3 steels may be easily made from scraps. The category 2 steels are in an intermediate position and require either a very careful selection of the srap or a partial use of pig iron or of "directly reduced iron" (D.R.I pellets).

\section{TABLE 4 : AVERAGE CONTENT OF RESIDUALS IN MOLTEN SCRAPS (10-3\% WEIGHT)}

\begin{tabular}{|l|c|c|c|c|c|c|c|}
\hline $\begin{array}{l}\text { Element content (in 10-3\% } \\
\text { Product / Application }\end{array}$ & $\mathbf{N i}$ & $\mathbf{C r}$ & $\mathbf{C u}$ & $\mathbf{S n}$ & $\mathbf{M o}$ & $\mathbf{N i}+\mathbf{C r}+\mathbf{M q}$ & $\mathbf{N i}+\mathbf{C r}+\mathbf{C u}$ \\
\hline Low residual & 40 & 30 & 60 & 7 & 10 & 80 & 130 \\
\hline Heavy scrap & 150 & 110 & 250 & 25 & 50 & 310 & 510 \\
\hline$N^{\circ} 4$ paquet & 80 & 30 & 80 & 9 & 20 & 130 & 130 \\
\hline$N^{\circ} 5$ paquet & 160 & 130 & 680 & 73 & 20 & 310 & 970 \\
\hline Scratched scrap & 140 & 80 & 260 & 36 & 20 & 240 & 480 \\
\hline PIG IRON & 15 & 20 & 11 & 5 & 15 & 50 & 46 \\
\hline
\end{tabular}


Concerning the non metallic elements, the situation is different.

Most of them may be economically removed from the liquid metal though the price is different depending on the chemical element.. However, phosphorous and sulphur may be industrially removed either in the liquid pig iron or in the liquid steel. In any case, a careful selection of the slags followed by vacuum degazing allows the achievement of low contents of the metalloïd elements " $\mathrm{C}, \mathrm{H}, \mathrm{O}, \mathrm{N}, \mathrm{P}, \mathrm{S}$ ". Nitrogen is perhaps the most difficult element to remove. Of course, this procedure is a lot easier when the initial content of these elements in the liquid steel is already low.

In this context an important fact is the rather high level of nitrogen which is reached after fusion in the EAF.Usual contents of 80-120 ppm are found whereas 20-50 ppm may be reached through the converter route.

Comparing these considerations with those developed in the previous section leads to a possible scenario for the production of each category of steel.

For the first category, the only possible route so far is the conventional one i.e. blast furnace and BOF followed by sophisticated ladle metallurgy and vacuum degazing. Because large blast furnaces are more efficient and because transportation costs of coal and iron ore are cheaper near the sea, these plants are usually located near the sea and have very large production capacities.

For the second category, the scrap-EAF route is possible provided that the scrap are carefully sorted. However to reach the required contents of $\mathrm{S}, \mathrm{O}$, and to a certain extend of, $\mathrm{P}$ and $\mathrm{N}$, it may be necessary to work in a reductive medium. In any case, a very sophisticated and highly productive ladle and vacuum metallurgy is necessary. There is no large scale industrial process in operation for the reduction fusion of scrap. However, different processes have been already tested on an industrial scale : Cupola, EOF, KVA, etc... This kind of plant would be of a smaller size and located near the consumption centers which are both scrap producers and steels customers.

For the third category, less sophisticated but very productive equipments are necessary. The scrap-EAF route is the best one. The plants will be typical minimills of average size, located near the consumption centers.

\section{5 - Technological change in the productive equipments.}

The above description doesn't take into account the technological changes in production equipment . Very large productivity increases have been achieved in the past for the blast furnace and the BOF. Though progress is still made, it is difficult to forsee any further major breakthrough. This is not the case for the vacuum metallurgy equipments. Reference (7) from which table 5 is taken, gives the forseen level of purity achievable with one of the most popular vacuum metallurgy device nowadays : The so-called Rheinstahl-Heraeus $(\mathrm{RH})$ process.

TABLE 5 : LEVEL OF METALLOÏD IMPURITIES WHICH MAY BE REACHED WICH THE RH PROCESS , FROM REFERENCE (9)

\begin{tabular}{|l|c|c|c|c|c|c|}
\hline \multicolumn{1}{|c|}{ ELEMENT } & C & P & S & N & $\begin{array}{c}\text { O } \\
\text { Solutio } \\
\text { n }\end{array}$ & H \\
\hline Nowadays equipement & 15 & 10 & 7 & 25 & 15 & 1 \\
\hline Forseen achievable content in year 2000 & 6 & 2 & 1 & 14 & 5 & 0,2 \\
\hline
\end{tabular}

The EAF may change appreciably in the future. The achievable content of nitrogen may be decreased thank to a better airtightness. The new development of direct current furnaces allow an improved design of the furnace (1). Furthermore, some gaz injection $\left(\mathrm{CO}, \mathrm{CH}_{4}, \mathrm{O}_{2}, \mathrm{Ar}\right)$ will be possible in industrial operation in the near future. This will allow some metallurgy inside the furnace itself. 
Finally, some improvements may be achieved in the preparation of scraps : in particular, crushing and sorting.

\section{3 - NEAR NET SHAPE CASTING}

The main recent changes in the casting of steel are the development of a wide variety of technologies to cast the steels in sizes very near the final shape required for their applications.

Some processes are already used.For example the CSP and ISP processes for the direct casting of slabs of 30 to $50 \mathrm{~mm}$ thickness. This is also the case for the direct casting of "dog bone" shape blooms for the production of beams.

Other processes are in development now. The so-called CPR process for direct slab casting is beginning its operations in the Ruhrort plant of Thyssen. Thin strip casting of $2 \mathrm{~mm}$ thick coils is developed in many places around the world, especially by Nippon steel and Usinor-Sacilor (8). Direct casting techniques of wires are also under development, such as the "Gradic" process for $1 \mathrm{~mm}$ diameter wires and the "Ironwasp" process for thiner diameters.

In any case, a large development of the near net shape casting is foreseen in the near future. A japanese study of 1990 (10) gives projected proportions of flat products cast through these processes in the near future. $30 \%$ will be produced using the conventional continuous casting machines. $60 \%$ will use the thin slab casting techniques and only $10 \%$ will use the direct strip casting process.

What will be the metallurgical implications of such a major change? We will assume that the quality of the surface may be as good as for the more conventional processes. The very elevated heat fluxes flowing out of the surface of the products will induce a primary grain growth perpendicular to the surfaces. The size of the primary grains varies from one product to the other and the possibilities of grain refinement by downstream processing must be taken into account in the choice of the casting technology for a given steel grade.

\section{1 - High formability fine steels}

For these steels, very large deformations are necessary at ambiant temperature. If the surface quality is sufficient, it may be assumed that the conventional continuous annealing lines give the required properties. Perhaps, in some cases, a double treatment may be necessary to fulfill the deformation down to the final dimensions.It may be inferred that thin strip casting will be widely used in the future. However, some amount of rolling at hot temperature may be necessary for certain grades in order to have a fine structure before cold rolling. That is why the thin slab casting will probably be of a wider use in the future since some hot working takes place downstream of the casting process.

\section{2 - Special fine steels}

In this case, the final shape is usually larger and thermal heat treatments are necessary.The purpose of these treatments is usually to get a fine structure. This, in turn, requires some deformation at higher temperature to get enough recristallisation.

The desired metallurgical structure is sensitive to the grain size and the retained dislocation density at the end of the hot rolling. Therefore, the casting must be not so near to the final shape because a minimum of hot working is necessary. Moreover, in these products, the control of the segregation is also very important. A large amount of hot temperature deformation is also favorable in this respect.

\section{3 - Commodity steels.}

For these products, the cold formability required is less important and the metallurgy of these products does not need a very precise structure.

\section{4 - ON STREAM METALLURGY AND REDUCTION OF THE OFF LINE HEAT TREATMENTS.}

Another major trend is the reduction of all the off line heat treatments. There are several developments which have suppressed these heat treatments. This includes, of course the continuous annealing lines used in the large flat products plants but also the so called thermomecanical control process (TMCP) which is of wide use in the manufacturing of plates with quarto mills. The aim is the obtention of a well defined structure thanks to a careful scheduling of the deformation and temperature paths. The same concepts are used for wires and for bars. Indeed,some steels have been developed to enable the final 
properties to be obtained in the as hot forged product. Mainly the steels of the second category are concerned by these techniques, though some kind of simplified TMCP is used for some products of the third category such as concrete reinforcing rods or certain beams.

\section{5 - INCREASE OF THE PROPORTION OF COATED STEELS.}

The surface of steels are modified for mainly two reasons. The first one is, of course, to protect them against corrosion. The second one is a local hardening of the base metal to improve its wear or fatigue properties.

In this field,two trends are noticed. First, the proportion of steels with some kind of coating has dramatically increased in the past years. For example, the production of coated thin sheets has doubled between 1974 and 1991.

In the meantime, a wide variety of different ways of coating have been industrially developed. Concerning the anti-corrosion coating, the more conventional hot-dip galvanisation is still progressing every year. More sophisticated baths incorporate aluminium, magnesium or even iron itself, so that a corrosion resistant alloyed layer is formed. This requires a further rapid heat treatment. Besides the hotdip technique with $\mathrm{Zn}, \mathrm{Al}$, the electrodeposition technique is becoming increasingly important. It allows the production of very regular thin layers of $\mathrm{Sn}, \mathrm{Zn}, \mathrm{Ni}, \mathrm{Cr}$, etc... Finally, new techniques under vacuum are being developed: CVD, OMCVD, etc.... On the metallic coatings are deposited organic layers for their colour, of course,but also to improve the corrosion resistance. Very complex coatings are produced nowadays with successive layers of metallic alloys, conversion treatments, organic paintings, etc... This leads to a very large variety of products.

The same trend is seen for the surface hardening treatments for which new techniques such as ion implantation, are developed besides the more conventional carbon and nitrogen surface enrichment.

Therefore, in the future, many, if not most, of the products will have modified surfaces. For the very thin products, either sheets or wires, the proportion of products modified near the surface may be large enough to influence the global property of the product : for example the deformability of the coating is no longer negligible in galvanized thin sheets !

\section{CONCLUSION}

After a birds eye survey of the trends in steelmaking, what conclusions may be drawn?

I shall try to describe the different kinds of plant that we may forsee for the future. Of course, it is a difficult exercice because only technical factors are taken into account. Quite obviously, social, cultural and political factors will be of the outmost importance; so that the real evolution may be far from the one presented below.

Starting from the partition of the products into three categories, three different kinds of plants may be defined.

The first one produces high formability fine steels. Liquid iron is produced from iron ore through the conventional route: blast furnace and converter. The purity of the steel reaches very elevated levels thank to the development of vacuum metallurgy. Most of the products have very fine dimensions and near net shape casting will develop.Some amount of working at high temperature may be necessary in most products. This means that "not so near net shape casting" will develop first. The liquid steel plant will produce only a very limited list of different chemical compositions. Thanks to large shops for the continuous heat treatment and coating of the steels, a wide variety of products will be produced due to the different continuous heat treatments used and to the different coatings. These plants will preferably be very large and highly automated plants, preferably located near the sea. Between 35 and $45 \%$ of the production may be produced in this way.

The second one produces special fine steels. The liquid steel may be produced from scrap, but the required purity in metalloïd elements is also high. Therefore, sophisticated EAF will be used together with vacuum metallurgy treatments. Conventional continuous casting will continue to be used because thermomecanical controlled processes will continue to develop requiring large amounts of hot working. Surface Hardening treatments will concern a wider proportion of the products. These plants are smaller than the previous ones and are located closer to the second transformation plants. 
The third kind of plant corresponds to the typical mini-mill with an efficient EAF, some limited amount of ladle metallurgy followed by near net shape casting. Some on line heat treatments, hot-dip galvanizing or even organic coating are included in the plant.This means average size plants located near the consumption areas. These plants may concern $50 \%$ of the total production.

\section{Acknowledgments}

I want to thank MM. MICHARD, BIRAT, GUTTMANN, ROESCH, CHARBONNIER and THOMAS for the very interessing discussions we had together.

\section{References}

(1) A. BERTHET, JC. GROSJEAN "The 90's Electric Arc Furnace steelmaking route : the leap forward" International Conference on DC EAF, Nayoya (1990), Rapport IRSID DIR/RE/90/023

(2) J.A. MICHARD "Evolution des techniques d'élaboration de l'acier", Revue de Métallurgie - CIT, volume 88, (1991), p. 223

(3) H. FAURE "Dévelopment, state of the art and future aspects of steelmaking", European Oxygen steelmaking congress, Düsseldorf/Neub, 21-23, June (1993)

(4) J.P. BIRAT : "Scenarios for the technological evolution of the steel industry", Promt - 92, Düsseldorf 30 Nov-2Dec (1992)

(5) B. THOMAS : "Proceedings of the $10^{\text {th }}$ Riso International symposium on Metallurgy and materials science" ; (1989), J.B. Sorensen et al. Editor, p. 675

(6) L. ROESCH : "Contribution to the $3^{\text {rd }}$ USINOR SACILOR / NSC meeting on steel production routes. The impurities of the EAF route and their effect on steel properties", rapport IRSID RI/91/352

(7) E. HÖFFKEN, W. BADING, E. HEES, H.P. HAASTERT, F.J. HAHN : "Vakuum und Entwicklung des RH Verfahrens in den Stahlwerken der THYSSEN Stahl AG", Thyssen Technische Berichte 24 (1992) H1.S1 - 144, p. 69

(8) J.P. BIRAT : "Les aciers en bandes minces", La Recherche 240, volume 23, (1992), p. 150

(9) Tekko kaiho, 1494, $1^{\text {st January (1990) }}$ 